\title{
The Impact of Rape on Rape Victims and the Characteristics of Rapistsin Sri Lanka
}

\author{
Prof. M.W. Jayasundara \\ Department of Criminology and Criminal Justice, University of Sri Jayewardenepura, Sri Lanka
}

\begin{abstract}
In Sri Lanka, the women were regularly protected in the past by their family members and the comminity. But owing to the modernization and social changesin the country,the status previously enjoyed by womenspecially as regards to their protection has changed. Within this senario as men, the womentoo have started movingmostly alone in the society.In consequence some men seek sexual gratification in socially unaccepted manners. Thus, the rape of women has increased rapidly for the last two decade. The rape rate has plunged forwards from 6.8 in 2001 to 8.2 to in 2019. The increse in the number of rape incidents in the country has created a real conundrum for women as well as for the peaceful existance of the whole society.
\end{abstract}

This study was carried out with the objective of identifying the nature and causes of rapes and the impact of rapes on the victimsin the society at large. Further, the nature of the rapists was also amain concern of this study. The data were collected by conducting semi-structured interviewes and case studies with 60 victimes of rape, selected from twelve districts consisting of 3 to 8 victimes from each district in Sri Lanka. The study has revealed that less educated women between 16 to 25 years of age haveoften becom victims of rape than in the other age categories. However, thewomen over 65 years of age had become victims. The mentally retarted and the disabled women have often been the easy praysfor rapists and those who were alone at home during the day time also had become the victims of rape. Of the perpetrators $85 \%$ were known to the victims and their relatives, their lovers and neighbours had also been found among them. Ignorance,deception, loneliness and isolation at home, walking alone shady roads, physical or mental disabiltities were the main casuses to have fallen victims of rape.Among the perpetrators $20 \%(n=12)$ were alcohol abusers while $13.3 \%(n=8)$ were drugs and alcohol abusers.

The study suggests that the provision of proper protection for women who walk alongthe solitary roads and the women who stay all alone at home minimize the number of rape victims. Further young women should be educated with respect to the impact of forced sexual intercourse and deception by men for their mere sexual gratifiction.

\section{INTRODUCTION}

Thra n many countries of the world, rape is considered to be a grave crime committed against women. This is mostly due to the fact that women have acuired equal rights and preveledges as compaired to men in their economic, political and social spheres. Consequently, women have lost the traditional protection given by parents and their guardins and they often have to move in the society alone for their daily activities round the clock. The loss of traditional protection enjoyed by the women has paved the way for some men to have their sexual desires fulfilled through illegal means. The sexual crimes including rates of rape cases have shown an increase in Sri Lanka in the last two decades.

Figure 1: Rape Rates in Sri Lanka 2001-2019

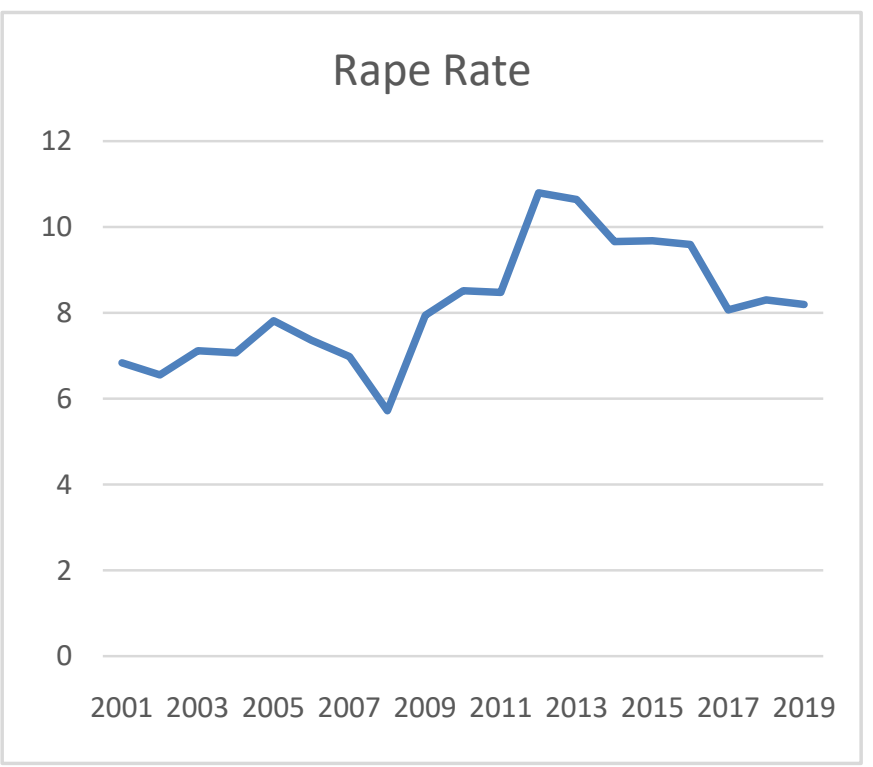

Source: Report of Inspector General of Police 2001-2019

A higher incidents of rape are shown during the last two decades of 2001-2019 in Figure 1. Accordingly, a gradual increase in the rate of rape cases from 5.72 in 2008 to 10.80 in 2012 can be observed. Since then the rape cases have shown a slow decrease slowely upto 8.2 per 100,000 by 2019 . However, when compared to the incidence of rape rate 6.84 in 2001 the recent rape rate (8.2) indicates a higher level as in 2019.

In Sri Lanka rape is considered as a grave crime comitted against females. According to the Penal Code of Sri Lanka a man is guilty of rape when it is committed against her will or her consent.Sri Lankan Penal Code further explains that penetration is sufficient to constitute the sexual intercourse necessary to the offence of rape. The punishment for the perpetrator is prescribed as rigorous imprisonment of a term which may extend upto twenty years, and shall also be liable to a fine (Penal Code of Sri Lanka, 1833:390).However, the punishment for rape still remains as death penalty in many countries and some countries like India death penalty is 
imposed especially on gang rapists while other rapistsarepunished with rigorousimprisonment.Even in America, in its history of punishment against rape carried heavy penalties. For example, of all executions carried out during 1930 and 1965, 12 percent were against rape (Livingston,1992:193). Apart from the physical harm caused by the action of rape, the psychological harm affects the victim very badly. The effects of rape give rise to posttraumatic disorders which consist of extreme fears, abhorence, sleep disturbances, various sexual symptoms and aberant behavior that last sometimes for years. The sufferings of a rape victim may vary with respect to her relationship with the perpetrator.The behaviour of the rapist ismostly accompanied by violence or cruelty during the rape.The victim's general psychological and physiological health, her general expectations about male-female relationships, and the support she receives from others are most likely to impact on her life. But it is difficult to measure the degree of suffering of a rape victim as it is considred a hidden crime. Rape victims often keep hiding their victimization owing to shame, embarrassment, fear of letting others know as there is a social stigma attached to it.The desire to avoid further questions both by the criminal justice officials and the neighbours is often due these reasons. Further, the victimes might not report the rape incidence to the police thinking that it is a personnal matter of them and they might also fear retaliation from the perpetrator.

In western countries rape is assumed to be a menace in the society as it occurs often as compared to the other countries. For example, in the United States of America a rape incident occurs every 10 minutes. It is estimated that there are on average 55,000 victims of rape and approximately 80,000 offenders every year in the United States of America (Qadri,1977:127).In the USA, many teenagers and college girls become victimes of rape as a result of their cultural practices like fraternities and sororities in college campuses. It is estimated that date rape or acquintance rape covers 60 to 80 percent of rapes in America. Owing to the culture that provides a set of values and beliefs conducive to rapes in colleges, 1 out of 4 college women reveal that they were raped or experienced an attempted rape, and 1 out of 12 college men say that they forced a woman to have sexual intercourse against her will (Adler and Adler, 2007:171). One college student who forced sex on a female friend wrote "Alcohol loosened us up and the situation occurred by acciedent. If no alcohol was consumed, I would never have crossed that line" (Abbey 2018). In England one in four women has been subject to a sexual assault or rape. In England and Wales during the period of 2004 to 2005 there were 60,000 sexual crimes recorded by the police (Bull et.al, 2006:168).

Unlike in western countries, Sri Lanka has a very long history that entails protection for women in Sinhalese society.More than 2000-year-old Buddhist texts explain sexually deviant behavior among monastic communities, specially engaging in sex with anmials and human corpses (Sigel, 2010:430).
Further the advice given to laymen by the Lord Buddha includes the ill-effects of having sexual relations with other women rather than one's own wife. In the past women did not enjoy the same power and independence as equal to their male partners. It is explained in relation to the status and duties of women in Hindu Laws of Manu which originated in the sixth century B.C. (Radhakrishnan and Moore, 1957:190-1). Traditionally in Sri Lanka, women were protected by their parents or guardians exerting effective surveillance on them. Therefore, the opportunities were less for males to develop intimate contacts with females becausewheneverthe women went out atodd hours or visited remote or secluded places they were escorted.

With the advancements in science, technology, international trade and the rapid expansion and sophistication of mass media during the later part of the twentieth century everyone has become a member of the global village. At present, family members do not work together as an entire unit, instead, they work in factories and state or private institutions as individual employees. The economic role of the family has changed with the passage of time. Thus, family has been transferring its economic function to the external agencies. Consequently, women in the families have become more independent by being economic partners in their families. Sometimes the woman has become the bred-winner of the family whereas the husband plays the role of the wife which is the performance of household chores.

Freda Adler points out that when social and economic role of women changes in the legitimate world, their participation in crime will also change (Adler, et.al 1995:42). With the gender equalization of socio-economic activities, women have become more vulnerable to be the victims of sexual offences including rape. This study attempts to find out the impact of rape incidents on victims and nature of rapes committed in Sri Lanka.

\section{RESEARCH PROBLEM}

In the past, Sri Lankan family members worked together in fields or farms for the production of their goods. A clear-cut division of labor was maintained by men and women in the family and every family was self-sufficient in ancient times. Traditional societies have protected womanhood and kept effective surveillance on women by either parents or guardians. There were very minimal opportunities for women to meet the members of the opposite sex. Girls not allowed to visit out-of-the-way places either unescorted or odd hours.Accordingly, the woman's father protected her in childhood, her husband protected her in youth and her sons protected her in old age. A woman is never fit for independence (Radhakrishnan and Moore, 1957:190-1).

With the advances in science, technology, international trade and the rapid expansion and sophistication of mass media over the later part of the twentieth century everyone has become a member of the global village. Consequently, women in the families have become more independent by being an 
economic partner in their families. Sometimes the woman has become the bred-winner of the family whereas the husband plays the wife's role that is the performance of household chores. The equalization of socio-economic activities of both males and females has led to similar behavior patterns, both legal and illegal, on the path way of both men and women.Presently, women enjoy more independence and they move alone in the society without any protection thereby facilitating sexual offenders to grab them easily for sexual offences. Consequently, the incidence of rape has increased from 6.84 in 2001 to 10.2 in 2012 and slight decrease of 8.2 in 2019. The reported figures of rapes may be misleading as the rape is considered to be the most hidden crime among the grave crimes and it goes often unnoticed like a tip of the floating iceberg. This study has focused its research problem as to why there is an increase in rapes in Sri Lanka and why people are predisposed to rape females and with what motives and theimpact of rape on the victims.

\section{Objectives}

- To identify the effects of rape on the victims

- To identify the causes of rape in Sri Lanka

- To determine the nature of rapists and the incidence of rape

\section{Significance of the study}

Though there had been a few researches conducted to determine the nature of victimization of rape, both the impact of rape on victims and the nature of criminal behavior of the rapists have not yet been examined adequately by research in Sri Lanka. Therefore, this research will undoubtably be significant for both academics and the policy makers to work towards an extensive program on the prevention of rape incidents and policy planning. The research will also generate new knowledge as regards the criminal behavior of rapists and the causes and motives that lead to commit such crimes. Further, the effects of rape on the victims and the understanding of the extent of their suffering would help victims to be protected and rehabilitated.

\section{METHODS}

The study was carried out with respect to the rape victims selected from twelve districts. Figure 1 indicates the number of cases selected from each district. A number of victims from 3 to 8 were chosen from each district on convenient sample drawn from the data available in selected police stations. Selected victims were met at their houses and was collected the data by interviewing them using interview schedule. Interviews were designed primarily to gather data on the impacts of rape on the victims, the nature of incidents and the motives of criminals that drive them to rape females. This semi-structure open-ended procedure took approximately forty minutes per victim. However, the length of the interview was subject to a considerable individual variation. An assurance of confidentiality and a voluntary nature of participation were established with those who participated at the interviews.

Figure1: Sample units selected from each selected district

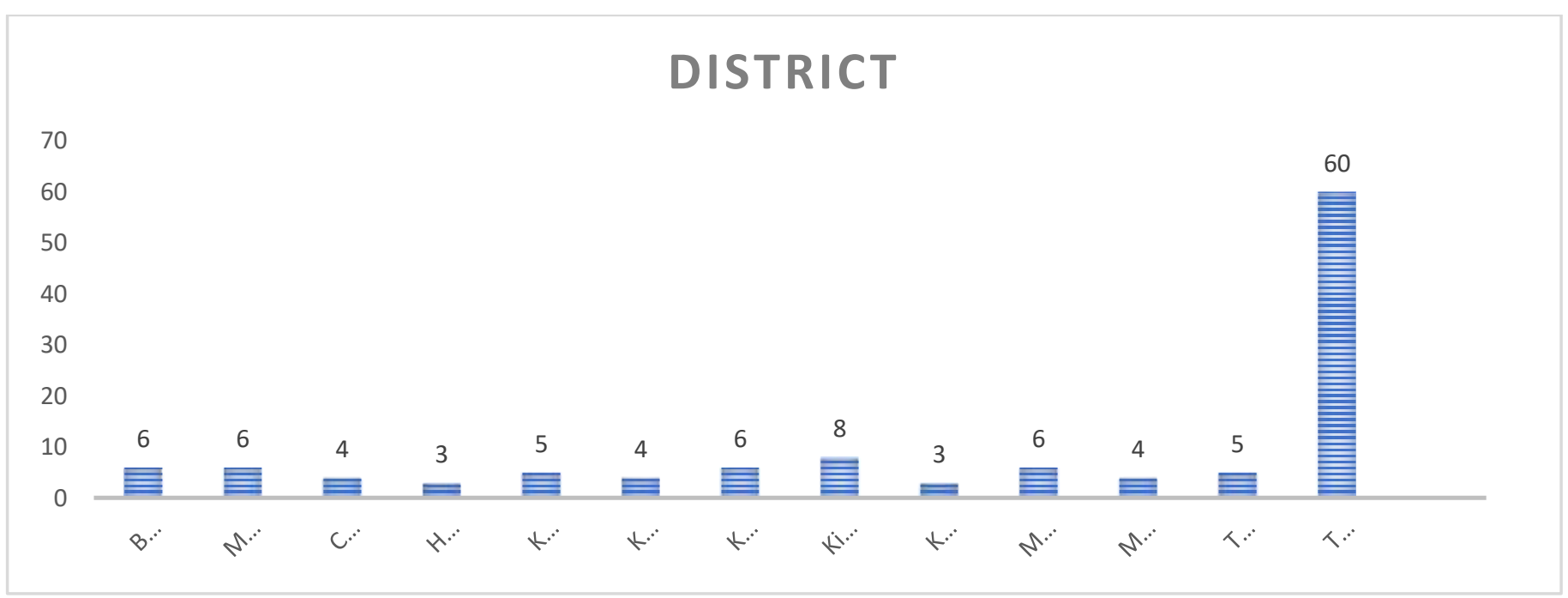

Source: Field Research 2019

In this study both qualitative and quantitative date were collected regarding the impacts of rapes on victims and the behavior of the rapists. In analyzing data, standard data analysis methods were utilized to achieve the objectives of the study.

\section{Theoritical Background}

In order to understand the behavior patterns of rapists the new light shed by the criminological theories on the causes of rape was paid attention to.There exist a varity of theories that explaine the causes of rape on different assumptions. According to feminist theorists, rape is learned behavior and it 
is motivated by power rather than sexual desire, and all men are capabel of it ( Wales; Hemmens, 2011). Although social learning theorists comply with these assumptions they hold the view that rapists are abnormal and they are psychologically unhealthy males. The views of the therapists who work with rapists assert that rape is sexually motivated and all male are potentially rapists (Mealey, 2003). Evolutionary Psychologists also believe that rape is sexually motivated and it is a maladaptive consequence of a generally adaptive behavior of males seeking as many sexual partners as possible (Thornhill., Palmer., 2000). According to somebiological explanation sex offenders caary higher testorone levels produced in testicles and stronger sexual urges which drive them to commit sexual offences. When male sex hormorne keeps increasing they tend to be more amorous and aggressive. Further, studies have continued that more violent males have higher level of testorone in their systems. However, the diffrence in testorone levels would account for at least some of the diffrences in crime rates between the male and the female (Vold,; Bernard.,1986:98). Biochemical imbalances may also occur due to inadequate or improper diet. Some studies have shown that criminals suffer from vitamin deficencies, cerebral allergies or low blood suger yet they do not explain to what extent nutritional conditions are related to criminal and deliquent behavior. Some theorists suggest that sexual offences are learned at young age by rapists which pays prepaeration and justification of outrageous sexual actes. Still, some other theorists are of the view that sex offending occurs because these offenders have never learned how to keep or carry on appropriate and constrctive relationship with others (McNamara, 2014:226) It is obvious that these offenders commit rape as they cannot find sexual outletsthrough accepted association or maintain interactions with the women that they yearn for.

\section{DATA ANALYSIS AND FINDINGS}

Figure 2. Age distribution of rape victims

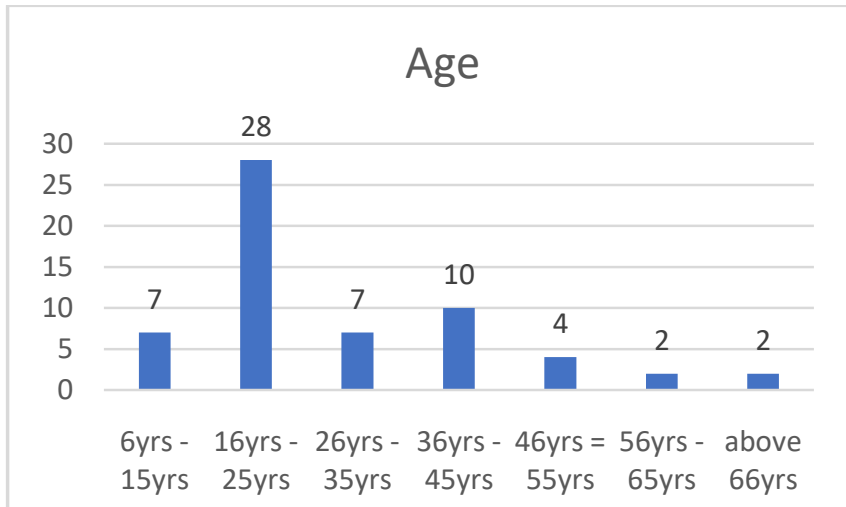

Source: Field Research 2019

The present study was conducted on 60 victims of rape selected from severalpolice stations in different districts of Sri Lanka. Their age distribution is indicated in Figure 2. Accordingly, the highest number of victims (46.7\%) belong to the age group of 16-25 years. The second highest group numbering $10(16.7 \%)$ of victims represents the age 36 to 45 years. However, the children belong to the age group 6 to 15 years numerically 7 (11.7\%) also represent the victims of rape and the same number of victims represents the 26-35-year age group. Further two $(3.3 \%)$ women who belong to the age group 56 to 65 had also been victimized by the rapists. Another two (3.3\%) elderly women over 66 years of age were among the rape victims.

Figure 3: Race of the Rape Victims

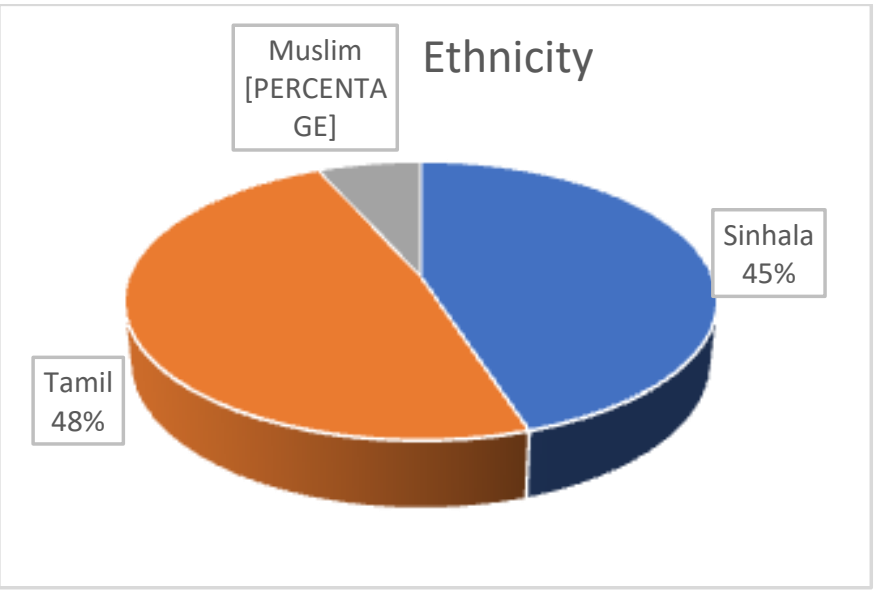

Source: Field Research 2019

Among the individualistic factors that affect rape, the race of the victim was significant because it indicates the fact that though the Tamils are a minority group in Sri Lanka the highest racial group (48\%) who had been selected in the sample comprised the Tamils. The reason for this was that sample was selected mainly from the areas where Tamils were predominant. As Figure 3 indicates the second highest group (45\%) was from the Sinhalese and the lowest group (7\%) of victims represented the Muslim women.

Figure 4: Educational Standard of the Rape Victims

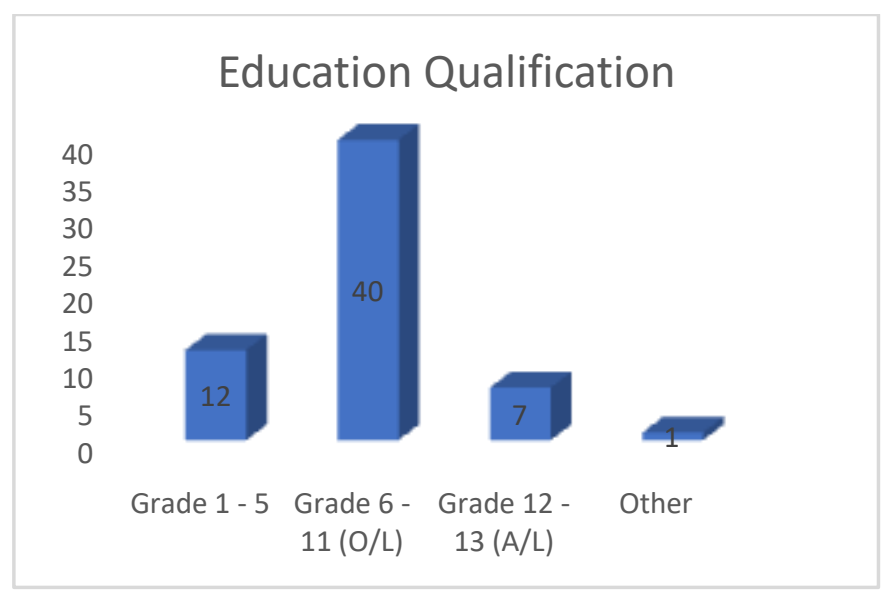

Source: Field Research 2019

Figure 4 shows the standard of education of the rape victims. The low standard of education of the victims reveals that there is a correlation between the low education and their being 
victimized. Accordingly, the majority $86.7 \%(\mathrm{n}=52)$ of the victims had ordinary level or lower education standard and of them $20 \%(\mathrm{n}=12)$ had received education from grade $1-5$. The low education standard of the victims implies that these women can easily be cheated or frightened by rapists to achieve their targets. The victims must have mostly faced the incident of rape without any shrewdness but with resignation as compared to the educated women due to their low standard of education. However, $13.3 \%(n=8)$ of rape victims had acquired higher educational qualifications with Advanced Level. These women may have been raped by intimidating them.

Figure 5: Civil Status of the Rape Victims

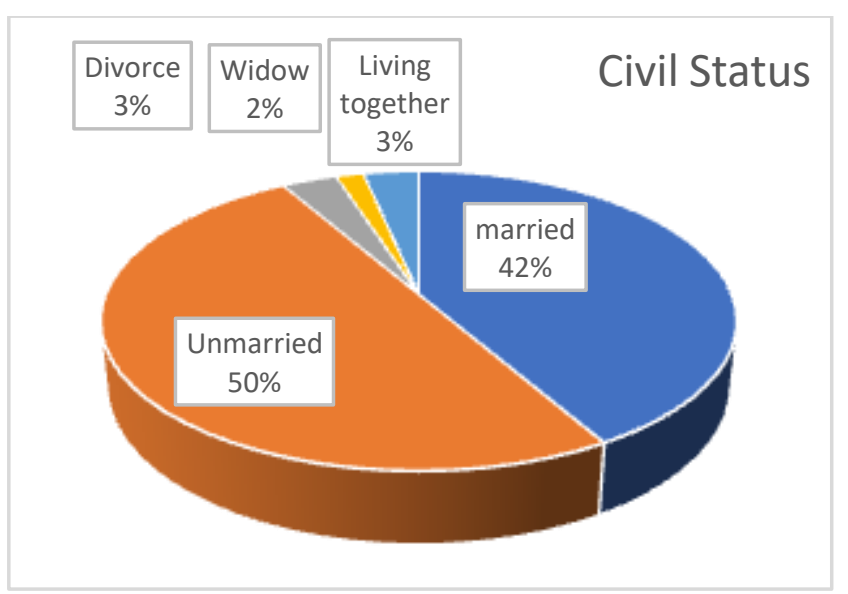

Source: Field Research 2019

According to Figure 5, the marital status of the victims can be interpreted as follows. 50\% $(\mathrm{n}=30)$ of the victims were unmarried while $42 \%(\mathrm{n}=25)$ were married. In the present study there were two (3\%) rape victims who hadlived together with their husbands though they were not married legally. Another two (3\%) were divorced from their husband and one (2\%) victim was a widow. It is assumed that most of the women who are unmarried and living alone frequently become the prey of rapists in Sri Lanka.

Table 1: Special Characteristics of the Rape Victims

\begin{tabular}{|c|c|c|}
\hline Special Characteristic & Frequency & $\%$ \\
\hline Mentally handicapped & 6 & 10 \\
\hline $\begin{array}{c}\text { Both mentally and physically } \\
\text { handicapped }\end{array}$ & 1 & 1.7 \\
\hline Physically handicapped & 1 & 1.7 \\
\hline Being Ignorant & 12 & 20.0 \\
\hline Deceived by boy-friends & 12 & 20.0 \\
\hline Others & 28 & 46.6 \\
\hline Total & 60 & 100 \\
\hline
\end{tabular}

Source: Field Research 2019

Table 1 indicates the special physical and mental characteristics of the victims of rape. Accordingly, some victims $(10 \%)$ were mentally handicapped and two victims
(3.3\%) were physically handicapped. Another $20.0 \%(n=12)$ were ignorant and they had no realization as to the adverse effects of being raped. Collectively, all those victims had easily become the prey of the rapists as they did not have much awareness of the effects of rape incidents. On the other hand, rapists often believe that women with mental and physical problems may not react against them by disclosing the incidents to others as compared with the women who are of normal characteristics. There were another $20.0 \%(n=12)$ victims who had been cheated and raped by their lovers and $8.3 \%(\mathrm{n}=5)$ of them had become pregnant and delivered babies at the end.

Figure 6: Time of the incidence of rape occurred

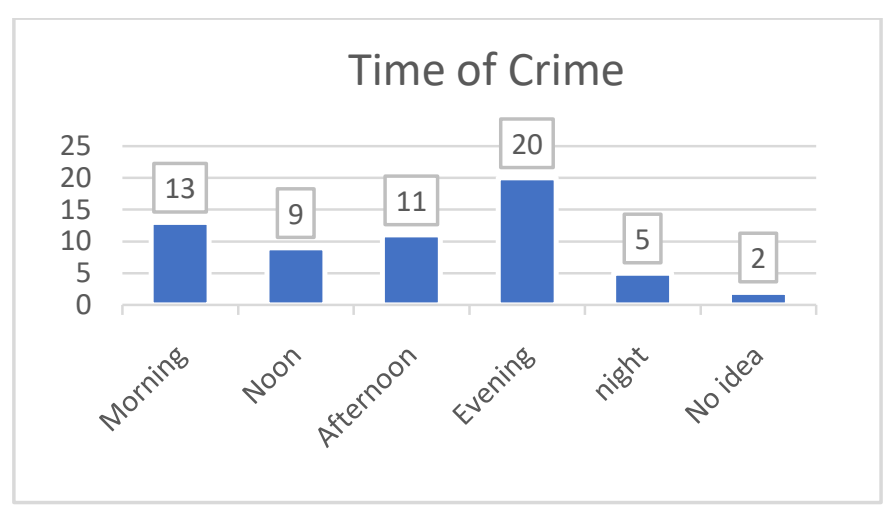

Source: Field Research 2019

The time of rape incidents occurred was a concern of the present study. Figure 6 shows that most of the incidents had occurred in the evening as the working women often returned home alone in the evening and rapists manage to prey onthem in outside places in the evening. Those who were at home alone had become victimized in the morning as well as in the day time. However, the relatives who were at home with the victims had also committed rapes during the day time. Those who worked in garment factories frequently had been raped in the evening or night when they returned home after work and they had been kidnapped by gangs or by their ex-boyfriends and raped at night.

Table 2: Causes for the Rape

\begin{tabular}{|c|c|c|}
\hline Causes for the Rape & Frequency & $\%$ \\
\hline Being alone at home & 20 & 33.3 \\
\hline Easily deceivable & 8 & 13.4 \\
\hline Kidnapping & 8 & 13.4 \\
\hline Drive to forest forcefully & 6 & 10 \\
\hline Victim being deaf & 2 & 3.3 \\
\hline Taking revenge by ex-husband & 1 & 1.7 \\
\hline Gang rape & 2 & 3.3 \\
\hline Returning alone after work & 2 & 3.3 \\
\hline No answer & 11 & 18.3 \\
\hline Total & 60 & 100 \\
\hline
\end{tabular}

Source: Field Research 2019 
The causation of crime against humans takes place due to various reasons. As a social being an individual interacts with the other members of the society especially with the people in his or her community. When people have unfulfilled desires and when they fail to fulfil them in socially and culturally accepted wayssome follow illegal methods to get their drives fulfilled. Similarly, people who cannot satisfy their sexual needs with females in socially accepted ways resort to threat and physical force to have sex with women against their will. They are looking forward to the opportunities available in the society. As Table 2 shows $33.3 \%$ of females had been victimized when they were alone at home. Females being alone at their home provides opportunity for perpetratorsto gratifytheir sexual desires easily. Another method of achieving the sexual desire of rapists is by practicing deception on their girlfriends. In the present study $13.4 \%$ of females have been caught by their lover's deception. In some occasions, rapists have used their force to kidnap and rape females when they were alone at home or when they were solitary on the road. Further, some rapists had taken(10\%) females into forests or dense shrubberies forcefully and there they had raped these victims as they wished. One individual had raped his ex-wife as a means of avenging himself on her. As it was mentioned earlier, mentally and physically disabled women had become the easy preys of the rapists.

Figure 7: Complaint Made to the Police

\section{Complaint made to the Police}

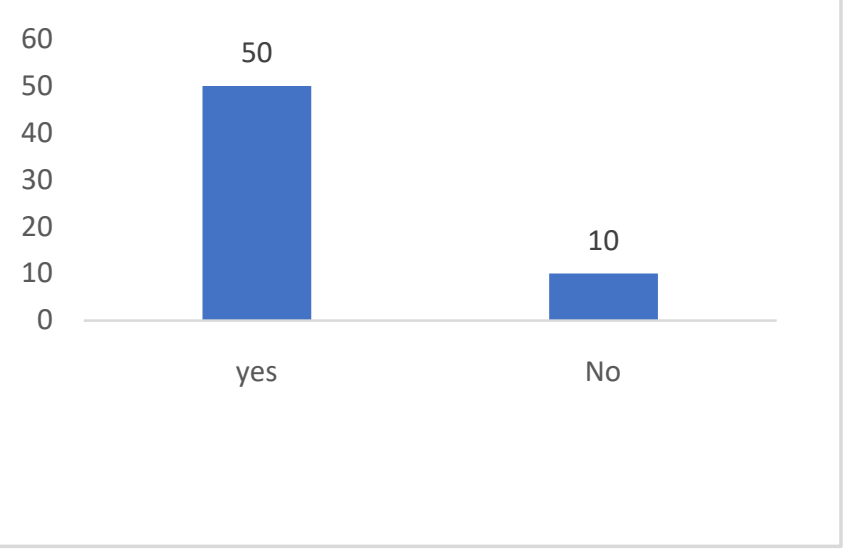

Source: Field Research 2019

It is a common phenomenon that rape cases are not often reported to the police as victims knew their perpetrators. The true proportion of non-stranger rapes such as the women raped by relatives, lovers and neighbors is higher than that of the women raped by strangers. In the present study 50 (83.3\%) had reported their cases to the police while $10(16.7 \%)$ did not report their victimization to the police due to the fact that their relatives, lovers and acquaintances were involved in their being raped.
Figure 8: Age Distribution of the Rapists

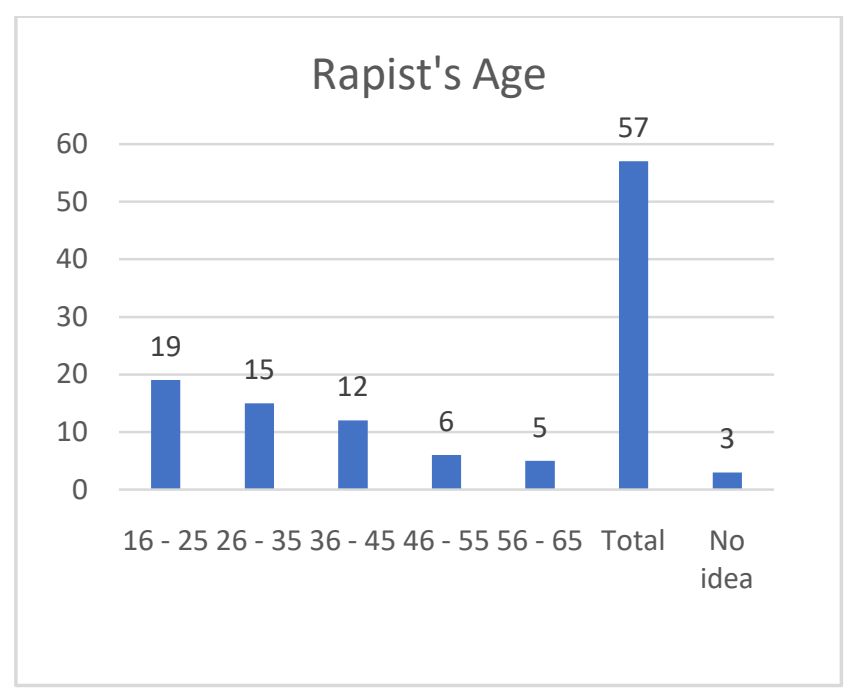

Source: Field Research 2019

Figure 8 shows the age distribution of the rapists. Accordingly, the highest number $(\mathrm{n}=19 ; 31.7 \%)$ of them belong to the age group of 16-25 years and the same category of age group of victims were the highest age group (48.7\%) of victims. Those who belong to this category of age are considered as highly motivated individuals who are eager to have sexual experience mostly for the first time in life. The second and the third highest number of rapists represent the age groups between 26-35 and 36-45 respectively. The lowest number of rapists falls under the age group between 56 to 65 years of age.

Table 3: Addictive behavior of the rapist

\begin{tabular}{|c|c|c|}
\hline Nature of the Addictive behavior & Frequency & $\%$ \\
\hline Alcohol use & 12 & 20 \\
\hline Drugs and Alcohol & 08 & 13.3 \\
\hline Womanizing & 12 & 20 \\
\hline Uncertain & 28 & 46.7 \\
\hline Total & 60 & 100 \\
\hline
\end{tabular}

Source: Field Research 2019

The findings of the study reveal that the rapists have frequently taken to alcohol and drugs and at the time that they committed the rape they were under the influence of alcohol and drugs. In general, the consumption of alcohol and drugs are deemed to encourage or facilitate the criminal behavior of the perpetrators and influence them to lower their inhibitions, impair judgements, and increase their recklessness and risktaking behavior. The substance abuse and its relationship to crime may vary with regards to the factors of the amount and type of substance consumed, the background and the personality of the user, and the social situation in which substance is used. Table 3 indicates that $20 \%$ of the rapists have used alcohol while $13.3 \%$ of them have used both alcohol and drugs. According to the research conducted on 
alcohol use it has different effects on different people and even on the same person at different times. In taking small amount of alcohol most people tend to experience enjoyable and cheerful feelings while taking moderate or large amount of alcohol they tend to develop aggressive and violent behavior as alcohol consumption impairs judgements, lowers frustration tolerance, and induces disinhibition (Curran and Renzetti, 1994:122). Within this scenario it can be assumed that some prefer to get intoxicated as a way of easy achieving their unfulfilled desires such as committing rape as it is believed that alcohol often does what the drinker expects to do. In other words, alcohol drug users use these substances to avoid the inhibitions that they have in their minds against rape.Further, the table 3 indicates that there were $20 \%$ of rapists who had showna desire to seduce women lecherously. These people often engaged in womanizing whenever opportunity was available especially when they found females alone in conducive environment to commit rape.

Table 4: The impacts of the incidence of rape on victims

\begin{tabular}{|c|c|c|}
\hline The impacts on victims & Frequency & $\%$ \\
\hline $\begin{array}{c}\text { Getting unwanted fear over } \\
\text { incidence }\end{array}$ & 4 & 6.7 \\
\hline Being repentant & 22 & 36.7 \\
\hline Being pregnant & 5 & 8.3 \\
\hline Killed after rape & 2 & 3.3 \\
\hline Committed suicide & 1 & 1.7 \\
\hline Absent at employment & 6 & 10 \\
\hline Threatening to withdraw the case & 4 & 6.7 \\
\hline $\begin{array}{l}\text { Arrange a legal marriage with } \\
\text { perpetrator }\end{array}$ & 2 & 3.3 \\
\hline Sabotaged life & 6 & 10 \\
\hline No response & 8 & 13.3 \\
\hline Total & 60 & 100 \\
\hline
\end{tabular}

Source: Field Research 2019

The present study was concerned about the impact of the incidence of rape on the victims. As Table 4 indicates two victims were killed after the act of raping.A 74-year-old woman was killed by a boy of 16-years after raping her and another woman was killed by a male gang after committing rape. Further, a woman had committed suicide as a result of strong repentance on having succumbed to rape. Moreover, $8.3 \%(\mathrm{n}=5)$ of the rape victims had given birth to a child as an aftermath of their being subject to rape. Almost all the victims said that they hada repentance over the incidence of rape while $10 \%(n=6)$ of victims had given up their employment due to the stigma created by the rape incidents.Perpetrators and their family members had threatened four victims to withdraw their court cases against them. However, two victims were married by their perpetrators.

\section{Case Study 1}

This incident has occurred to a 22-yearold diabatic patient called Nimali. She has also been suffering from a mentalillness since her younger age.She used to go to Peradeniya hospital with her parents every Sunday to take medication for diabetics. One day on her way to hospital she had received a several telephone calls from an unknown phone number, and then her father has informed the caller not to call their daughter any longer andrequested him to meet her parents. Another day, on her birth day, when she had gone to the hospital to take medicine, the person who called her had come to meet her and had taken her by a green-colored threewheeler. In the evening, she had called her parents and told them that she was with that particular person named Jayalath and they had bought a house in Hantana, Kandy where they were going to live and she would not come home again. Before the occurrence of this incident the parents of the girl had sought information about Jayalath but they did not succeed. Jayalath had kept the girl one night in a hotel and had seduced her. The following day he had dropped her at Peradeniya and sent her home by a three-wheeler. The victim had told her parents that she would remember the place where she was kept during the previous day by persuasion. Then the parents of the girl had tried to find the place and had travelled up to Anuradhapura but they failed to find the hotel. As they knew the number of the three-wheeler by which she had been sent home, they have made a complaint at the police. Later, the information regarding Jayalath was found by the Children and Women Bureau of the police and subsequently Jayalathwas arrested. The person's real name was Gunawardene and he was a married person. Later his spouse had come to the victim and threatened her.As a result, the victim had injected an over dose of insulin for her diabetics and had been hospitalized. After that incident Jayalath had been produced at the court by the police and the court had released the culprit on bail ordering him to appear before the police once a month, but the victim had not yet received any compensation.

\section{Case 2}

The victim of this incident was a 74-year lady who lived alone in her house. She conducted a Montessori at her house with the assistance of a young-lady-teacher. On that fateful day, the young teacher had been with her until 1.00 p.m. A boy of 16 who lived nearby by house used to visit her frequently and therefore he was known to her. The victim used to provide him with food and beverage and also books and other required materials for his schooling. On that day the weather was gloomy and the boy had entered the house and raped her ending up in murder. After murdering the old woman, he had raped her again and finally the perpetrator had dressed her well and kept her body on a bed. As the perpetrator said, everything had finished by 6.00 p.m. on that day. The victim as a teacher had taught the perpetrator and his father as well.

The following day, this incident had come into surface as she did not sweep her compound and a light wereon at the night. Then, the neighbors had informed her children about their missing mother and they had come to the scene quickly. When they entered the house the victim's body was lying sprawled on the bed as if she was asleep. The police had investigated the case and found that someone taller than the victim had 
committed rape and killed her as a jug was seen kept on a somewhat tall cupboard. Police had found the cloth belt used for strangulating the victim at the perpetrator's house and DNA test has confirmedthe evidence of killing the old lady by a young boy. Consequently, the boy was arrested and produced before the court and legal actions were taken against him.

\section{Case 3}

Charmali is a mentally handicapped divorced woman who lived in Kaduwela. She lived with her elder brother's family in her parental house. She used to go to her elder sister's house to look after her disabled child during the day time as her sister worked in a garment factory. Elder sister's husband had raped her when she was alone at his home. This incident was kept as a secret by Chamali until she got pregnant. Then, her brother's wife had inquired about her pregnancy and the person who was responsible for it. She had disclosed all the details of the incident to her sister-in-law and a case hadbeen filed against the rapist by the police and this case is still being heard at the court. Now she is back at home and her one and half year-old child is growing in a Children'sHome.

\section{Case 4}

Somalatha is a 30-year-old deaf mute woman lived in Dambulla. She had been undergoing a training in a beauty salon. She had been deceived and raped by one of her relatives after taking her to a hotel in the area. She could not disclose the incident to her family members though they had noticed her changing figure. Later the family members of the victim had informed the police and a case was being heard in the high court. Due to this incident she has lost her job and has suffered continuous physical and mental agony.

The above mentioned four case studies explained in detail the causes of rapes and the nature of the victims and rapists. Correspondently, all the victims were disabled and suffered from physical or mental inability. One victim was over 74 years old and she did not have enough strength to cope with the incident and at the end she succumbed to death. Other victims had become an easy prey of the rapists as they were handicapped. All the rapists seemed to have been sexually motivated and maladaptive to engage in such crimes. They may have been psychologically aberrant as well.

\section{CONCLUSIONS}

This study was aimed at conducting a research on the "impacts of rapes on victims" and the nature of the perpetrators of rapes. Accordingly, data were gathered and analyzed in line with the objectives of the study and the following conclusions were drawn.

With the advancement of science and technology, the traditional protection given for women in Sri Lanka has declined and women have acquired almost equal socioeconomic and political status compared to males in the society. Correspondently, opportunities are available for pleasure seekers to have illegal sexual intercourse with women and consequently more and more women have become the victims of rapes in Sri Lanka.

The present study reveals that the highest number (46.7\%) of victims belongs to the 16-25 years of age group. The second highest group (16.7\%) represents the 36-45 age group. Further, 6-15 aged children and the elders over 65 years of age were among the rape victims. The causes for being victimized were also taken into consideration of the study and it was revealed that low standard of education was a contributory factor to be rape victims. Correspondently, $86.7 \%$ of the victims had obtained less than grade 11 standard of education and among them $20 \%$ had lower than grade 5 educational level. A half of the number $(50 \%)$ of the victims in the sample were unmarried and $42 \%$ were married. There were $3 \%$ of victims who had got divorced and the similar number had been living together with their male partners while one woman had become a widow.

It was a common characteristic that physical and mental handicapped women had become an easy prey of rapists. Correspondently, $13.4 \%$ victims of the study were handicapped women. Further,the girls under 15 years of girls and less educated women had hardly any understanding of the repercussions of rapesand obviously they are ensnared by the rapists. $20 \%$ of women had been deceived and raped by their lovers. The majority of rapes $33.3 \%$ had taken place in the evening and $21.7 \%$ had occurred in the morning and those who were alone at home hadmostly been raped in the morning.

The causes of rapes were the main concern of the study and it was found that being alone at home was the cause for $33.3 \%$ of women to fall victims of rape. There were $13.4 \%$ of victims who were easily deceivable and therefore they were subject to skillful amorous maneuvering and they had been cheated and raped by their lovers and boyfriends. A similar number of women who were returning after their work had been kidnapped and raped by both known and unknown people and some women $(3.3 \%)$ had been forcefully taken by threewheelers and thereafter they had been raped by gangsters. Further, some women had been raped due to their physical and mental handicaps and perpetrators appeared to have deemed that they could escape from their crime as the victims would not able to explain properly that they had been raped. Some women (3.3\%) had become the prey of sexual attackers as they were walking alone the road after work in the evening.

It is a common phenomenon that the incidents of rape often go unreported. Similarly, in the present study also, $16.7 \%$ of victims had not reported of their being raped to the police as the rapes had been committed by their relatives, lovers and close acquaintances.

The study was concerned about the characteristics of perpetrators of rape as well. Accordingly, 31.7\% ( $\mathrm{n}=19)$ rapists were within the age group of 16-25 years. The second highest age group of rapists consisted of 26-35 years and their 
number was $25 \%(n=15)$. However, $8.3 \%$ of rapists $(n=5)$ belonged to the age group of 56-65 years. The nature of substance abused by the rapists was also a concern of the study. Accordingly, 20\% of rapists had taken to alcohol and $13.3 \%$ were addicted to drugs and alcohol. Another $20 \%$ of rapists were identified by the victims as individuals who were in the habit of having sex with women.

The effects of incidence of rape on victims were also a concern of the study and it was revealed that $36.7 \%$ of victims repented over their being raped while $8.3 \%(n=5)$ of victims had given birth to a child. Another $10 \%(n=6)$ declared that their life was destroyed by the rapists. As a result of raping, two $(3.3 \%)$ women had been killed while another woman (1.7\%) had committed suicide. Some victims (10\%) declared that they had stopped going to their jobs owing to the shame created by being a rape victim of rape. Some of the victims $(6.7 \%)$ suffered from mental illness after the incidence of rape and they said they would experience fear psychosis when they remember the incident of rape.

The study proposes that the rape rate can be reduced in Sri Lanka by persuading women not to remain at home alone specially during the day time as many of the rapes occurred during the day time and when victims were alone at home.Further, women should be precluded from walking alone on the secluded roads in the evening after their work. Further, females have to be educated on the ill-effects of having premarital sex with their lovers as it often leads to unnecessary pregnancy.

\section{REFERENCES}

[1] Abbey, A. (2019) Alcohol-Related Sexual Assault: A Common Problem among College Student. In ncbi.nlm.nih.gov//pmc/articlesPMC 4484270/ Retrieved 31.12.2020

[2] Adler, F., Mueller, G.O.W., Laufer, W.S. (1995) Criminology. New York: McGraw-Hill, Inc.

[3] Adler, P.A., Adler, P. (2007) Sociological Odyssey. USA: Thomson Wadsworth Bull R., Cooke, C., Hatcher R., et.al. (2006) Criminal Psychology a beginner's guide. Oxford: One World Publications.

[4] Curran, D.J., Renzetti C.M. (1994) Theories of Crime. USA: Allyn and Bacon

[5] Livingston, J. (1992) Crime and Criminology. New Jersey: Prentice-Hall Inc.

[6] McNamara, R.H., (2014) Juvenile Delinquency: Bridging Theory to Practice. New York: McGraw Hill Companies, Inc.

[7] Mealey, L. (2003) Combatting Rape: Views of an evolutionary psychologists.

[8] In R. Bloom \& N. Dess (Eds.), Evolutionary Psychology and Violence (pp. 83-113). Westport, CT: Praeger.

[9] Penal Code of Sri Lanka (1883) Colombo: Ceylon Government Press.

[10] Qadri, S.M.A. (1977) AHMAD SIDDIQUE'S Criminology: Penology and Victimology. Lucknow: Eastern Book Company.

[11] Radhakrishnan, S., Moore, C.A. (1957) A Source Book in Indian Philosophy.NJ: Princeton University Press.

[12] Reports of the Inspector General of Police, 2001-2019.

[13] Siegel, L.J. (2010) Criminology: Theories, Patterns and Typologies. USA: Wadsworth.

[14] Thornhill, R., \& Palmer, C. (2000) A Natural History of Rape: Biological Bases of Sexual Coercion. Cambridge: MIT Press.

[15] Vold, Bernard (1986) Theoretical Criminology. Oxford: Oxford University Press.

[16] Wales, A., Hemmens, C. (2011) Introduction to Criminology. USA: Sage Publication Inc. 